\title{
IDENTIDADES DOCENTES, CHARGES E CRISE DO/NO MAGISTÉRIO: EFEITOS DE SENTIDOS
}

\author{
Joseane Spies ${ }^{1}$ \\ Dóris Maria Luzzardi Fiss ${ }^{2}$
}

\begin{abstract}
Resumo
São vários os modos de se dizer/fazer professor, o que faz pensar sobre: como as representações constituídas produzem efeitos na produção de sentidos sobre ser professor? Como elas podem nos influenciar? Sendo estas as questões de uma pesquisa qualitativa apoiada na Análise de Discurso francesa (Michel Pêcheux), pretendemos compreender os efeitos de sentidos manifestados em um gênero textual específico - a charge. Foram analisadas dez charges, procurando perceber sentidos associados aos professores com base em Stuart Hall, António Nóvoa, Maurice Tardif, Gilson Pereira, Cláudia Pereira Vianna, Marisa Vorraber Costa, Menga Lüdke e Eni P. Orlandi. O efeito de sentido de crise do/no magistério apareceu nas charges articulado à precarização salarial, feminização do magistério, relação diferente com os alunos e com certas instituições, remetendo a uma produção de sentidos em torno do docente que evidencia tanto um funcionamento discursivo parafrástico quanto polissêmico.
\end{abstract}

Palavras-chave: Identidades Docentes; Charges; Discurso

\footnotetext{
${ }^{1}$ Licenciada em Pedagogia (UFRGS), Professora da EMEF Leocádia F. Prestes (Secretaria Municipal de Educação de Porto Alegre). Endereço:Rua Jerônimo Coelho, n. 209/ap. 11 - Centro Histórico/ CEP 20010-241 Porto Alegre (RS). Endereço eletrônicojoseane.spies@gmail.com.

${ }^{2}$ Graduada (Licenciatura Plena) em Letras Português/Inglês e respectivas Literaturas pela Pontifícia Universidade Católica do Rio Grande do Sul (1991), Mestrado (1996-1998) e Doutorado (1999-2003) em Educação pela Universidade Federal do Rio Grande do Sul. É Professora Adjunta IV no Departamento de Ensino e Currículo (Área: Didática) da Faculdade de Educação (FACED) e Professora Permanente do Programa de Pós-Graduação em Educação (PPGEDU) da Universidade Federal do Rio Grande do Sul (UFRGS). Endereço: Universidade Federal do Rio Grande do Sul, Faculdade de Educação. Av Paulo Gama, Centro, 90110-160 - Porto Alegre, RS - Brasil. Telefone: (51) 33084157. Endereço Eletrônico: fiss.doris@ gmail.com.
} 


\section{INTRODUÇÃO}

São vários os modos de se dizer e de se fazer professor $^{3}$. Cada educador fala sobre sua profissão de um modo particular, manifesta um jeito singular de ser e atuar. Isso tem provocado questionamentos acerca do que é ser professor: afinal, o que faz de um professor um professor? Considerando jeitos diferentes de se fazer e de se dizer professor, o que significa ser professor? Tais questionamentos fizeram pensar sobre outro aspecto associado à fabricação das identidades docentes: as representações produzidas na mídia, ou melhor, em charges, sobre o ser professor. Como o professor está significado nesses textos? Como as representações constituídas produzem efeitos na produção de sentidos sobre ser professor hoje? Como elas podem nos influenciar?

Em decorrência de tais inquietações, consideramos importante abordar a forma como são constituídas as identidades docentes em nossa sociedade e de que maneira os professores são representados em charges, visando à problematização dessas representações. Pretendemos compreender, pois, os efeitos de sentidos manifestados em um gênero textual específico - a charge. Como o professor é constituído aos olhos dessa ferramenta midiática? Que estereótipos são produzidos a respeito do professor? De que maneira o professor é representado nas charges? As charges retratam que tipo de professor? De que modo: estabilizando imagens já existentes ou as desmistificando?

Esse estudo é uma pesquisa qualitativa. O referencial teórico-metodológico em que se baseia o trabalho com o corpus (as charges) é a Análise de Discurso francesa proposta por Michel Pêcheux. Foram analisadas dez charges que circulam na internet (blogs e redes sociais), procurando perceber sentidos associados à docência e aos professores com base em autores que contribuem com o aprofundamento em torno dessas questões: Stuart Hall, António Nóvoa, Maurice Tardif, Gilson Pereira, Cláudia Pereira Vianna, Marisa Vorraber Costa, Menga Lüdke e EniOrlandi.

O efeito de sentido de crise do/no magistério apareceu nas charges articulado a efeitos de sentidos de desvalorização da profissão docente, precarização salarial, feminização do magistério, relação diferente com os alunos e com certas instituições. As análises revelaram uma produção de sentidos em torno do docente que evidencia tanto um funcionamento

\footnotetext{
${ }^{3}$ Embora saiba das implicações teóricas e políticas do uso da grafia o(s)/a(s) e partilhe dessa posição teórica, para uma maior fluência do texto, adotamos o gênero masculino para referir, respectivamente, a professores e professoras, alunos e alunas. A distinção será mantida quando for relevante à discussão realizada.
} 
discursivo parafrástico quanto polissêmico, produzindo marcas em nossa compreensão de docência.

\section{IDENTIDADES, DOCÊNCIA E (DES)PROFISSIONALIZAÇÃO}

\subsection{Umpouco de história da docência}

Desde a década de 70, o magistério é uma profissão em crise e as pressões que os docentes têm enfrentado, na forma do aumento de controle, fragmentação do trabalho, perda de autonomia, diminuição salarial e queda de prestígio, têm sido associadas ao fenômeno da feminização do quadro docente. Se, como sublinha Costa (1999), com base em Stuart Hall (2003), o processo de constituição das identidades pode ser compreendido a partir de seu caráter cultural, ou seja, "contribui para a formação das nossas identidades não apenas o que dizemos ou pensamos que somos, mas os diversos discursos sobre nós que, além de nos representar, nos intimam a ser da forma como dizem que somos" (p. 4-5), nada mais necessário do que percorrer um pouco da história da docência, nela garimpando elementos que têm influenciado na fabricação das identidades docentes.

Segundo Costa (1996, p. 15), a atividade docente se constitui a partir de profundos vínculos ligados à cultura e à tradição. É essencial o ser humano se integrar em um grupo, assimilar e assumir a sua cultura, no entanto, a forma como isso ocorre se diferencia no tempo e no espaço, registrando continuidades e rupturas. O diálogo com a tradição, com elementos do passado dessa ocupação, pode contribuir para a compreensão de algumas de suas idiossincrasias.

Sócrates, Platão e Aristóteles foram os filósofos precursores da pedagogia humanista, influenciando fortemente na noção de uma pedagogia comprometida com a sociedade e a verdade. Esse legado grego associou o magistério a um certo caráter ético-moral. Nesse período, a atividade docente era exercida exclusivamente por homens, existindo uma divisão entre mundo masculino (o mundo público) e feminino (o mundo privado). A cobrança pelos ensinamentos era repudiada pelos romanos, pois o pagamento indicava servidão, de modo que os educadores eram discriminados. Consoante Costa (1996), nas escolas criadas para atender a emergente classe de comerciantes e artesãos, 
SPIES, J.; FISS, D. M. L.

os mestres (ludi magister) eram antigos escravos, velhos soldados ou proprietários arruinados que se estabeleciam com uma loja de instrução para sobreviver em uma sociedade que se transformava. Apesar de serem homens livres, esses professores precisaram trabalhar para prover sua existência e isto os fazia assalariados, sendo seu ofício comparado a qualquer outra atividade social desprezada e inferior. (p. 16).

Na Idade Média, a Igreja assume o controle da fundamentação dos princípios morais, políticos e jurídicos da sociedade, assumindo, também, o monopólio da educação. Os monges são os únicos letrados. Nem os nobres sabiam ler e, para instruir os novos irmãos nos mosteiros, os padres eram os professores. Com o surgimento de uma nova classe, a burguesia, surgem as primeiras escolas de leigos, ainda baseadas na formação das escolas dos monges, no entanto, com professores nomeados por uma autoridade. As escolas eram nas portas das igrejas, em esquinas, ou numa sala emprestada, onde os alunos sentavam no chão, "eram próximas umas das outras e os professores esperavam pelos alunos como comerciantes esperam pelos fregueses, competindo entre si” (COSTA, 1996, p. 16).

As primeiras Universidades surgem no século XII e, conforme Costa (1996), introduzem a tradição escolástica que inventa uma "arte de pensar" baseada em codificação formal e peculiar, com função didática, inscrevendo-se como força formadora de hábitos. A escola, como é conhecida hoje, surgiu no século XVI, caracterizando-se como responsável pela reprodução das normas e pela transmissão cultural, para formar, disciplinar e adaptar os sujeitos. No século XVIII, com as mudanças de poder nas sociedades e o crescimento da importância dos trabalhadores, os professores deixam de ser os padres para, então, os leigos se tornarem funcionários burocráticos, apesar de, para o Estado, o modelo de professor estar muito próximo ao dos padres. "Essa influência dos componentes religiosos persiste, até hoje, na cultura do trabalho docente. Por sua vez, os conteúdos do ensino, ou que ensinar, foram sempre objeto de lutas e controvérsias, estabelecidas a partir do exterior da profissão" (COSTA, 1996, p. 17).

No século XIX, para obter licença para ensinar, os professores são submetidos a concursos ou exames para comprovar que possuíam os requisitos: conhecimento, boa conduta, sendo então aprovados pelas normas sociais controladas pelo Estado, legitimando, assim, o papel social do docente. Isso passa a ter grande importância e, com a crescente demanda pela escola, surgem as primeiras propostas de formação especializada e as primeiras escolas normais para preparar professores primários.

No Brasil, em 1835, foram fundadas as primeiras escolas normais, sendo o acesso à escolarização elementar regulamentado para mulheres em 1827, mas não em níveis mais 
elevados. No currículo da escola normal, em 1871, surge a distinção entre formação das professoras e dos professores. Para as mulheres, o curso normal não visava formar a professora, mas preparar a boa mãe de família.

Esse suposto caráter feminino da profissão é acentuado com a intensificação da presença das mulheres nos quadros docentes, contribuindo para que sejam estabelecidas associações entre a atividade do ensino, a maternidade e a afetividade das mulheres. Isso contribui para o declínio do status social da ocupação e complica sua identificação com as agendas profissionais. (COSTA, 1996, p.18).

Essa representação social de docência como trabalho de mulher foi incorporada pelas mulheres devido a elementos de uma suposta "natureza feminina". Como salienta Costa (1996),

A diferenciação, nestes cursos, entre os currículos para homens e para as mulheres, longe de representar avanços na conquista de espaço profissional pelo contingente feminino, expressava a tentativa de incorporar elementos associados a uma suposta "natureza feminina", os quais iam, igualmente, sendo introjetados na representação social da docência como trabalho de mulher (p. 18).

Uma das dificuldades na profissionalização de docentes é, por um lado, a contradição presente no profissionalismo como um movimento de domínio restrito e privilegiado de atuação masculina e, por outro, a condição das mulheres que historicamente têm sido um grupo dominado e discriminado social e culturalmente:

[...] estimular as conexões entre o gênero feminino e as esferas de atuação que se constituíram com vínculos históricos com o mundo doméstico, privado, contribuiria para manter as mulheres subtraídas da participação democrática no domínio público e atrelaria a constituição de suas identidades sociais às políticas neoconservadoras em andamento. (COSTA, 1999, p. 6).

\subsection{Profissão docente, profissionalismo e (des)profissionalização}

O profissionalismo, conforme Costa $(1996,1999)$, é uma estratégia que implica lutas políticas pelas quais um grupo legitima privilégios e recompensas, acionando mecanismos de segregação, autoprotecionismo e hierarquia. As profissões tiveram sua autoridade formal e pública legitimada por se utilizarem do estatuto da ciência, como um regime poderoso de verdade, e tendo como exemplo a profissionalização, a ciência e o poder, que estão 
SPIES, J.; FISS, D. M. L.

estreitamente ligados nesse processo. Comparada com outras áreas do conhecimento, a educação tem enfrentado dificuldades históricas para afirmar-se no campo científico. Ela vem sendo rejeitada, porque os conhecimentos que constituem seu contexto de ação e investigação não são legitimados pelo discurso presente nas demais ciências. Segundo Costa (1996),

No caso da docência, estão quase sempre em jogo as peculiaridades de pelo menos dois campos epistemológica e politicamente distintos: o do conhecimento específico (as disciplinas) e o do conhecimento pedagógico (saberes com déficit em relação ao campo científico). As disciplinas em geral favorecem estratégias profissionalistas relativas ao seu campo. (p. 21).

Além disso, conforme Pereira (2001), que ratifica argumentos de Costa (1996, 1999), os professores têm enfrentado, desde a década de 70, "a dura experiência da desvalorização salarial, perda de amor-próprio e de queda livre do prestígio profissional - do diploma e das credenciais simbólicas" (p. 43). A questão da precarização do trabalho docente tem sido amplamente discutida e, tal como aparece hoje, o declínio da "profissão" docente tem sido atrelado à "perda de prestígio, de poder aquisitivo, de condições de vida e, sobretudo, de respeito e satisfação no exercício do magistério" (LÜDKE e BOING, 2004, p.1160).

A literatura sobre o tema profissão é bastante ampla e permite perceber características mais ou menos consensuais quando se trata de conceituar uma profissão. Apesar disso, certos aspectos são incompatíveis quando tentamos aplicar esse conceito ao magistério. Vários autores discutem a respeito do assunto e identificam características essenciais aos comportamentos profissionais.LüdkeeBoing (2004), baseando-se em Cogan\&Barber,assinalam quatro critérios comuns a todas as profissões:

a) uma profunda base de conhecimentos gerais e sistematizados; b) o interesse geral acima dos próprios interesses; c) um código de ética controlando a profissão pelos próprios pares; e d) honorários como contra-prestação de um serviço e não a manifestação de um interesse pecuniário. (p. 1161-2).

Maurice Tardif $(2000,2012)$, por sua vez, entende que existe somente um atributo comum a todas as profissões: a especialização do saber, sendo necessário, no que concerne aos saberes docentes, salientar que eles são personalizados, situados e carregam as marcas do ser humano. Razão pela qual abrimos um breve parágrafo a fim de antecipar algumas considerações a respeito dos saberes profissionais do docente. Como se disse, eles são personalizados e situados: o professor dispõe de um sistema cognitivo, mas não se reduz a ele, 
pois "tem uma história de vida, é um ator social, tem emoções, tem um corpo, poderes, personalidade, uma cultura, ou mesmo culturas, e seus pensamentos e ações carregam as marcas dos contextos nos quais se inserem" (TARDIF, 2000, p. 15). Os saberes são personalizados, porque, conforme Tardif (2000), são “apropriados, incorporados, subjetivados, saberes que é difícil dissociar das pessoas, de sua experiência e situação de trabalho" (p. 15).

Finalmente, os saberes carregam as marcas do ser humano, uma vez que os docentes trazem consigo as marcas de seu trabalho. Embora professores "trabalhem com grupos de alunos, devem atingir os indivíduos que os compõem, pois são indivíduos que aprendem" (TARDIF, 2000, p. 16). É a epistemologia que orienta o professor a conhecer e compreender seus alunos em suas particularidades individuais. E a sensibilidade em relação às diferenças entre os alunos é uma das principais características do trabalho docente.

Ao lado da dificuldade de estabelecer um conceito de profissão coerente com as especificidades do magistério, outro aspecto preocupa: a "desprofissionalização" do magistério. Lüdke e Boing (2004), a partir de Viviane Isambert-Jamati, acrescentam que, quanto à realidade da docência no Brasil, alguns pontos podem ser referidos na tentativa de compreender o processo de desprofissionalização dos professores: a "divisão da ocupação docente em corpos que representam realidades culturais bastante distintas, como é o caso dos professores do ensino fundamental, em suas séries iniciais, o antigo primário, ante os que lecionam da $5^{\text {a a }} 8^{\text {a }}$ séries, o antigo ginásio" (p. 1164); entre os grupos referidos, existência de "separações relativas aos interesses pelas diferentes disciplinas, que por vezes determinam traços nítidos de conotação profissional, mais que a simples integração funcional a um grau de ensino" (p. 1164-5) e diferenças quanto às exigências de formação; a erosão salarial e seus desdobramentos para a dignidade e o respeito de uma categoria profissional.

Procurar desvendar como, e a partir de que fatores, a identidade profissional de um grupo é construída, considerando que a definição de profissão não é clara, e questionar como a precarização do trabalho docente repercute na construção da identidade dos professores são aspectos importantes para serem discutidos. Conforme Lüdke e Boing (2004),

Quanto à identidade profissional dos professores, parece-nos que ela vem sofrendo, como a dos outros grupos ocupacionais, fortes repercussões das transformações ocorridas no mercado de trabalho, [...], dentro do magistério a questão da identidade sempre sofreu as injunções decorrentes de uma certa fragilidade, própria de um grupo cuja função não parece tão específica aos olhos da sociedade, especialmente 
SPIES, J.; FISS, D. M. L.

no caso dos professores do ensino elementar, a ponto de levar certos adultos a pensarem que qualquer um deles pode exercê-la. (p. 1168).

Segundo alguns estudiosos, contribui para essa fragilidade, o número crescente de mulheres que é considerado, por alguns, como um traço das semiprofissões. Outras fragilidades da profissão docente também podem ser destacadas: a entrada e saída da profissão sem o controle de seus pares; a falta de um código de ética próprio; a falta de sindicatos fortes; e, para finalizar, "a constatação de que a identidade "categorial" dos professores foi sempre atenuada, isto é, nunca chegou a ser uma "categoria" comparável à de outros grupos ocupacionais" (LÜDKE e BOING, 2004, p. 1169).

À medida que se faz a cisão entre o trabalho e a sua construção social, como ocorre com a retórica administrativa predominante nos dias atuais, maior precarização pode ser verificada nas diferentes profissões. Em nome de uma adaptabilidade às novas condições de trabalho criadas pelo capital, os trabalhadores abrem mão de conquistas históricas ou, como esclarecem Lüdke e Boing (2004), ocorre um afastamento dos professores de seu coletivo profissional decorrente da "lógica de responsabilização individualizante" (p. 1172) a partir da qual as competências são compreendidas e buscadas.

O profissionalismo, por sua vez, existe quando o sujeito faz a adesão individual ao conjunto de regras e normas de uma corporação, é neste instante que realmente começa a socialização profissional, uma escolha pessoal que faz pela profissão. Na profissionalização docente, o modelo de professor religioso, que envolvia a docência numa aura de vocação e sacerdócio, foi rompido com a estatização que foi um passo significativo rumo à profissionalização. No entanto, os docentes sofrem com a falta de autonomia - o que coloca em dúvida a existência de uma "profissão" docente. Além disso, a formação inicial já não basta, haja vista que é preciso a socialização profissional: “Somente a prática dará consistência ao repertório pedagógico que os professores foram assimilando ao longo de sua formação" (LÜDKE e BOING, 2004, p. 1174).

Enquanto se destaca o saber docente na sociedade da informação, é visível que a profissão de professor não tem o mesmo prestígio social, sendo isso, no mínimo, uma relação ambígua. Tardifet al. (1991), apontam cinco elementos explicando essa ambiguidade: divisão do trabalho (professores universitários assumem a pesquisa e professores da escola básica, a formação); a relação moderna entre saber e formação, mudando o foco dos saberes em si para procedimentos de transmissão dos saberes; a pedagogia passou a se subdividir em muitas 
especialidades em decorrência do aparecimento das ciências da educação; as instituições escolares são tratadas como uma questão pública; e a desconfiança dos diversos grupos sociais com relação aos saberes transmitidos pela escola, por avaliarem que estes têm pouca aplicabilidade na sociedade. (LÜDKE \& BOING, 2004).

Para Lüdke e Boing (2004), e considerando os desafios supramencionados, a missão dos professores vai além da cultura institucional. O professor tem um mandato específico na sociedade atual, seja no estabelecimento de ensino, seja em outros ambientes educativos, reais ou virtuais. O professor é um mandatário de quatro dimensões que o diferenciam dos outros intelectuais: é mediador, herdeiro, crítico e intérprete da cultura. Dessa maneira,

\footnotetext{
o professor é o fiel depositário da cultura, o herdeiro. Mas ele não recebe a cultura simplesmente. Como intelectual que é, ele é capaz de estabelecer elos entre os diversos saberes sobre o mundo, compreender como foram construídas as diferentes interpretações desse mundo e, conhecendo os estudantes, situá-los em seu contexto sócio-histórico. $\mathrm{Na}$ interação com seus alunos, ele necessita, constantemente, decodificar, ler, compreender e explicar os textos, situações, intenções e sentimentos. (LÜDKE; BOING, 2004, p. 1177).
}

A discussão acerca dessas dimensões representa uma perspectiva promissora para a valorização do magistério, propondo alternativas à precarização do trabalho docente. Para recuperar o prestígio da profissão docente e reverter a tendência histórica, que diminui a importância dos professores na sociedade, é necessário unir duas forças mobilizadoras: a parceria entre as instituições envolvidas com o desenvolvimento profissional do professor (Estado, agências formadoras e instituições contratantes) e a pesquisa a ser tomada pelo professor como fundamental ao seu trabalho, constitutiva dele.

Quanto à revalorização do professor, ainda cabe referir algumas propostas de António Nóvoa que se somam às sugestões de Lüdke e Boing (2004) e Maurice Tardif (2000, 2012). Consoante Nóvoa, (2009), os professores estão voltando à cena após anos de relativa invisibilidade: nos anos 70, foi o tempo de racionalização do ensino, da pedagogia; nos anos 80, surgiram as reformas educativas com a reforma do currículo; nos anos 90, deu-se atenção às organizações escolares, funcionamento, administração e gestão. No final do século XX, estudos alertaram para os problemas de aprendizagem, já no início do século XXI, reaparecem desafios com as questões da diversidade e das novas tecnologias. Seria dizer que o regresso dos professores ao centro das preocupações e das políticas decorre da necessidade de maior atenção para problemas relacionados à aprendizagem e, também, do surgimento de desafios (a 
SPIES, J.; FISS, D. M. L.

diversidade e as novas tecnologias da informação e comunicação) que exigem que se repense a escola em suas funções e dinâmicas.

Dois grupos contribuíram para produzir, renovar e divulgar os estudos sobre a profissão docente. O primeiro grupo são os investigadores da área da formação de professores, que tem como marca o conceito de professor reflexivo e fizeram uma reviravolta na compreensão sobre os professores e sua formação. O segundo grupo é formado pelos especialistas que atuam como consultores ou fazem parte de organizações internacionais. "Apesar de sua heterogeneidade, eles criaram e difundiram, no plano mundial, práticas discursivas fortemente alicerçadas em argumentos comparados” (NÓVOA, 2009, p. 6), dando maior visibilidade à docência, às suas especificidades e particularidades na contemporaneidade.

Contudo, importante destacar, com Nóvoa, que talvez os discursos relativamente à profissionalização dos professores possam contribuir para a melhoria do estatuto e prestígio dos especialistas sem exercer o mesmo efeito sobre a condição e o estatuto dos professores. $\mathrm{O}$ que se articula a outra consideração também importante: é necessário “construir políticas que reforcem os professores, os seus saberes e os seus campos de atuação, que valorizem as culturas docentes, e que não transformem os professores numa profissão dominada pelos universitários, pelos peritos ou pela 'indústria do ensino"” (NÓVOA, 2009, p. 7).

Além disso, o autor cita medidas que podem ajudar a superar os dilemas atuais em torno da aprendizagem docente e do desenvolvimento profissional, sendo fundamental, para isto: passar a formação de professores para dentro da profissão de tal modo que a "comunidade dos formadores de professores" e a "comunidade dos professores" estejam mais envolvidas nos fazeres uma da outra, mais integradas; promover novos modos de organização da profissão, investindo na constituição de comunidades de prática, ou seja, "grupos de educadores comprometidos com a pesquisa e a inovação, no qual se discutem ideias sobre o ensino e aprendizagem e se elaboram perspectivas comuns sobre os desafios da formação pessoal, profissional e cívica dos alunos" (NÓVOA, 2009, p. 9); reforçar a dimensão pessoal e a presença pública dos professores, construindo um conhecimento pessoal desde o conhecimento profissional e compreendendo a profissão de professor para além de matrizes técnicas e científicas.

Nesse sentido, há que se investir certo esforço conceptual que implica compreender a especificidade da profissão docente - o que demanda também, conforme Nóvoa (2009), 
repensar as redes de trabalho coletivo e o professor no seu fazer, nas disposições a partir das quais se fala em "bom professor" sem, no entanto, buscar uma definição fixa para isto. A fim de evitar as listas intermináveis de "competências" que costumam classificar os docentes, qualificando suas escolhas de modo questionável, Nóvoa (2009) sugere um novo conceito para disposição, rompendo assim o debate sobre as competências: "Adopto um conceito mais "líquido" e menos "sólido", que pretende olhar preferencialmente para a ligação entre as dimensões pessoais e profissionais na produção identitária dos professores" (NÓVOA, 2009, p. 14). Dentre as disposições do "bom professor", são destacadas cinco que, desde a perspectiva do autor português, são essenciais para compreender o ofício dos professores:

1. conhecimento: "O trabalho do professor consiste na construção de práticas docentes que conduzam os alunos à aprendizagem" (NÓVOA, 2009, p. 14);

2. cultura profissional: é a compreensão da finalidade do espaço escolar, a integração na profissão, a aprendizagem com os profissionais mais experientes;

3. tato pedagógico: é a capacidade de relação e de comunicação, sem as quais não é possível $\mathrm{o}$ ato de educar. Ter serenidade, conquistar os alunos, "saber conduzir alguém para a outra margem, o conhecimento, não está ao alcance de todos" (NÓVOA, 2009, p. 14), o que permite perspectivar que as dimensões profissionais cruzam, sempre, com as dimensões pessoais, sendo impossível separá-las;

4. trabalho em equipe: o exercício do trabalho em equipe implica num esforço coletivo e de colaboração, organizando-se em torno de "comunidades de práticas", no interior de cada escola. As "comunidades de prática", constituídas por grupos de educadores comprometidos com a pesquisa e a inovação, discutem, elaboram ideias sobre o ensino e a aprendizagem, reforçando, assim, o sentimento de pertença e de identidade profissional;

5. compromisso social: são princípios, valores, inclusão social, diversidade cultural elementos que constituem a realidade da escola e que obrigam o professor a ir além da escola uma vez que "comunicar com o público, intervir no espaço público da educação, faz parte do ethos profissional docente" (NÓVOA, 2009, p. 15).

No debate sobre o papel da escola no século XXI, Nóvoa (2009) argumenta que, no século XX, a "Escola se foi desenvolvendo por acumulação de missões e de conteúdos, numa espécie de constante transbordamento [...], que a levou a assumir uma infinidade de tarefas" (p. 24, grifo do autor). Ela acabou por se afastar, inúmeras vezes, das suas tarefas de ensino e aprendizagem para se dedicar às funções sociais, correspondendo, conforme a época, a uma 
SPIES, J;; FISS, D. M. L.

“instituição de regeneração, de salvação e de reparação da sociedade" (id. ibid.). Na atualidade, são demandadas outras tarefas da escola que a percebem como uma organização centrada na aprendizagem e comprometida com a valorização da arte, da ciência e da cultura, elementos da sociedade do conhecimento.

A escola centrada na aprendizagem só tem sentido se a sociedade se responsabilizar por funções que, até agora, são assumidas pela escola. Portanto, esta "escola do retraimento" é aquela que consegue se libertar de um sem-número de atividades e tarefas as quais passam a ser desempenhadas por outras instituições, dedicando-se mais ao que lhe é próprio, e se coaduna com duas grandes finalidades: "a transmissão e apropriação dos conhecimentos e da cultura" e "a compreensão da arte do encontro, da comunicação e da vida em conjunto" (NÓVOA, 2009, p. 30-31). É exatamente isto que a escola sabe fazer e faz melhor como lugar de aprendizagem, de relação e de comunicação em que se constitui, espaço que assume compromissos, também, com certas condições de cidadania.

A primeira condição da cidadania é mais aprendizagem. A escola precisa fornecer aos alunos instrumentos básicos do conhecimento e da cultura para que se faça escola cidadã, escola possibilitadora de cidadania. Um dos desafios é romper com a excessiva padronização escolar a que os alunos são submetidos, pois estes têm necessidades e aprendizagens em momentos diferentes que devem ser consideradas. A segunda condição da cidadania na escola é mais sociedade. Isto significa que "Uma escola é uma sociedade, e não uma comunidade" (NÓVOA, 2009, p. 32) (grifos do autor) e, de acordo com o autor português, "é preciso instaurar a escola como sociedade, como lugar de trabalho conjunto, como lugar de diálogo e da comunicação, como espaço de segurança, como uma sociedade na qual as crianças prefiguram e praticam uma vida futura" (p. 32).

A base de uma sociedade não são os afetos ou os gostos semelhantes, mas estar reunido, trabalhar em conjunto com respeito e enriquecimento mútuo, do que decorre a terceira condição da cidadania: mais comunicação. É correto afirmar que as instituições escolares são espaços da relação e comunicação, no entanto, por vezes, se comunicam mal com o exterior. "O "novo" espaço público da educação chama os professores a uma intervenção política, a uma participação nos debates sociais e culturais, a um trabalho continuado junto das comunidades locais" (NÓVOA, 2009, p. 33). Dessa forma, Nóvoa (2009), ressalta que "não há cidadania se os alunos não aprenderem, se não formos capazes de integrar todos numa escola com regras claras e democráticas de funcionamento, se a escola 
não comunicar com o exterior" (p. 33), se colocando todos estes elementos como possíveis propulsores de um movimento de revalorização da profissão docente.

\subsection{Os professores e seus saberes}

Conforme Tardif e Raymond (2000), "se o trabalho modifica o trabalhador e sua identidade, modifica também, sempre com o passar do tempo, o seu "saber trabalhar"” (p. 210, grifos dos autores), ou seja, os saberes ligados ao trabalho são temporais e, no caso do magistério, "a aprendizagem do trabalho passa por uma escolarização mais ou menos longa cuja função é fornecer aos futuros trabalhadores conhecimentos teóricos e técnicos preparatórios para o trabalho" (p. 210). Ademais, compreender e dominar esses saberes da profissão exige conhecimentos, competências, aptidões e atitudes que somente podem ser adquiridos em contato com a prática do trabalho, pois se originam dela.

A abordagem da relação entre tempo e saberes profissionais, do ponto de vista de Tardif e Raymond (2000), não é uma tarefa fácil. São raros os autores que tratam da questão, mas, nos últimos vinte anos, alguns estudiosos norte-americanos têm enfocado os saberes que servem de base para o ensino docente: o knowledge base. Diz-se que a prática docente é uma atividade que produz saberes que não podem ser confundidos com a aplicação de técnicas nem tampouco ser reduzidos aos conhecimentos adquiridos na universidade que, embora fundamentais para a prática docente, não são suficientes para o exercício do ofício.

Com relação à temporalidade e aos saberes, dois fenômenos são essenciais: a trajetória pré-profissional e a carreira do professor. A trajetória pré-profissional compreende as experiências familiares e escolares dos professores. Boa parte do que os professores sabem sobre o ensino, o seu papel de professor e como ensinar, se originam de sua própria história de vida. O futuro professor, ao longo da história de vida pessoal e escolar, incorpora conhecimentos, competências, crenças, valores que estruturam a sua personalidade e suas relações com os outros e são reatualizados e reutilizados de maneira não reflexiva, mas com grande convicção, na prática de seu ofício (TARDIF; RAYMOND, 2000). Desse modo, os saberes experienciais do professor não se baseiam unicamente no trabalho em sala de aula, mas também nas aprendizagens obtidas na sua trajetória escolar.

Contudo, os saberes anteriores à formação do ofício de professor, por si só, não bastam para abranger todo saber profissional e tornar possível fazer carreira no magistério. $\mathrm{Na}$ 
SPIES, J;; FISS, D. M. L.

trajetória profissional, "os saberes são temporais, pois são utilizados e se desenvolvem no âmbito de uma carreira" (TARDIF; RAYMOND, 2000, p. 217). Tardif (2000) caracterizou os saberes profissionais dos docentes, classificando-os em temporais, plurais e heterogêneos, personalizados e situados: "os saberes profissionais são temporais [...] pois são utilizados e se desenvolvem no âmbito de uma carreira, isto é, de um processo de vida profissional de longa duração do qual fazem parte dimensões identitárias e dimensões de socialização profissional, bem como fases e mudanças" (TARDIFF, 2000, p. 14). A construção progressiva de uma identidade profissional ocorre com a tomada de consciência dos diferentes elementos que fundamentam a profissão. Conforme Tardif e Raymond (2000), a própria carreira docente é um processo formador de conhecimentos, visto que o professor, ao iniciar a prática profissional, se depara com problemas e limitações e passa a adaptar o seu conhecimento prévio à realidade do seu trabalho, constituindo rotinas.

Em sua pesquisa e análise sobre os tempos e saberes profissionais, Tardif e Raymond (2000) constatam que: os saberes que servem de base para o ensino ou os fundamentos do saber ensinar não se reduzem a um "sistema cognitivo" que, como um computador, processa as informações a partir de um programa anteriormente definido. São três os fundamentos de ensino que acontecem em um só tempo: existenciais, sociais e pragmáticos. Nos fundamentos existenciais, o professor não é só um sujeito epistêmico, ele também pensa a partir da sua história de vida, com o que viveu, com o que acumulou com as experiências de vida, ou seja, não pensa somente com a cabeça, mas com a vida. Os fundamentos sociais do ensino são produzidos e legitimados por grupos sociais e, conforme Tardif e Raymond (2000), os saberes profissionais provêm de fontes sociais diversas e são adquiridos em tempos sociais diferentes. Enfim, os fundamentos pragmáticos do ensino estão intimamente ligados ao trabalho tanto quanto à pessoa do trabalhador: “[...] trata-se de saberes ligados ao labor, de saberes sobre o trabalho, ligados às funções dos professores" (TARDIF e RAYMOND, 2000, p. 236). Esses três fundamentos demonstram a extensão temporal dos saberes dos professores. Em relação à carreira e à socialização profissional, "é impossível compreender a questão da identidade dos professores, sem inseri-la imediatamente na história dos próprios atores, de suas ações, projetos e desenvolvimento profissional" (op. cit., p. 238).

Em resumo, pode-se dizer, com Maurice Tardif, que os saberes profissionais dos professores são plurais e heterogêneos, pois provêm de várias fontes (cultura pessoal, história de vida, cultura escolar anterior, universidade, conhecimentos curriculares, cursos, oficinas, 
experiências de trabalho) e "não formam um repertório de conhecimentos unificado [...], eles são, antes, ecléticos e sincréticos" (p. 14). Dito de outra forma, na ação, no trabalho, os professores optam por atingir diferentes objetivos, dos quais não se exigem os mesmos conhecimentos, competências ou aptidões.

\section{IMAGENS E VOZES: AS IDENTIDADES DOCENTES}

A Análise de Discurso de vertente francesa proposta por Michel Pêcheux implicou num trabalho sobre os sentidos produzidos em $\mathrm{dez}^{4}$ charges que tematizam a docência, considerando o funcionamento discursivo parafrástico e polissêmico respectivamente. Estas charges correspondem ao corpus analítico, tendo sido veiculadas em sites da internet (portanto, de domínio público), no período que vai de 2003 a 2013. Orlandi (2012) ressalta que a "Análise de Discurso visa compreender como um objeto simbólico produz sentidos" ( $\mathrm{p}$. 66). O objetivo do analista de discurso é explicitar os processos de significação que trabalham no texto, compreender como o texto produz sentidos por meio de seus mecanismos de funcionamento. O texto, desde a perspectiva do discurso, não é compreendido como uma unidade fechada, com um significado em si mesmo, pois ele tem relação com outros textos (existentes, possíveis ou imaginários), com suas condições de produção (os sujeitos e a situação) e com sua exterioridade constitutiva (o interdiscurso, a memória do dizer).

A Análise de Discurso não trata da língua ou da gramática, mas, como o próprio nome indica, do discurso que, conforme Orlandi (2012), tem a ideia de percurso, movimento. Ele não trata somente da língua ou da gramática, trata do uso que é feito ao ser expressado pelo ser humano. Neste trabalho com os movimentos e os sentidos, Orlandi (2012) chama a atenção para os processos parafrásticos e polissêmicos. O processo parafrástico reafirma a memória, o dizível, enquanto que os processos polissêmicos são o deslocamento dos sentidos, a ruptura de processos de significação. São duas forças que fazem tensão entre o mesmo e o diferente. $\mathrm{O}$ modo de significar o professor e suas identidades se dará no campo da paráfrase e da polissemia, retomando sentidos e estes sendo atualizados, buscando marcas destes funcionamentos discursivos nas charges, "pois a análise de discurso tem um procedimento

\footnotetext{
${ }^{4}$ Foram coletadas 69 charges segundo critérios que atentaram para a presença de referência a professores neste gênero textual. Depois, foram selecionadas dez charges para análise neste artigo, destacando que o material coletado oferece outras possibilidades de análises que se encontram em processo de realização.
} 
SPIES, J.; FISS, D. M. L.

que demanda um ir-e-vir constante entre teoria, consulta ao corpus e análise" (ORLANDI, 2012, p. 67).

\subsection{Charges: a materialidade linguístico-imagética}

As charges, para Costa (2011), compreendem um funcionamento diferente do discurso jornalístico verbal. Sendo um gênero opinativo, mostram fatos pelo ângulo da indignação e ironia. A charge surgiu no Brasil do século XIX, quando era conhecida como caricatura: "termo genérico aplicado a todos desenhos humorísticos, desde que desencadeassem o riso, a crítica escarnecedora e a sátira contundente" (MIANI, 2012, p. 38). Com o tempo, devido à associação com o retrato, pela semelhança da palavra caricatura com cara, e visando acabar com a comparação, a caricatura passou a ser compreendida como aquela imagem que carrega os traços mais evidentes de um fato ou pessoa, seus defeitos, para levar ao riso. A palavra caricatura provém do termo italiano "caricare", portanto, a palavra charge, que é herdeira da caricatura, segundo Miani (2012), "foi “conquistando o direito" de significar o desenho de natureza humorística, predominantemente vinculado à produção comunicativa impressa, com o objetivo de ilustrar e/ou apresentar uma opinião a respeito de determinado acontecimento histórico" (p. 39).

Assim sendo, a charge é uma modalidade de linguagem iconográfica, também se inserindo nesse contexto o cartum, a caricatura e as histórias em quadrinhos. Elas desempenham um papel social, pois alertam, denunciam, coíbem e levam à reflexão, tendo não somente a função de distrair. Para Miani (2012), uma qualidade da charge é a de se compor como um “instrumento de persuasão, intervindo no processo de definições políticas e ideológicas do receptor, através da sedução pelo humor, criando um sentimento de adesão que pode culminar com um processo de mobilização" (p. 40). No entanto, para Oliveira e Almeida (2006), poucos são os que compreendem charges e caricaturas em sua totalidade, pois elas dependem do contexto em que ocorrem e somente aqueles que são bem informados conseguem interpretá-las.

Para fundamentar a noção de estereótipo, Costa (2011) afirma: “a significação é sempre igual, fixa, estereotipada, tendendo à paráfrase" (p. 92). Os estereótipos levam a uma notória homogeneização do discurso, pois circulam entre as diferentes camadas sociais, atravessam gerações e reforçam uma obrigação de repetição. Em contrapartida, o processo de 
homogeneização abriga outros efeitos de sentidos que não são os estabilizados: são efeitos de repetição que são confirmados pelo senso comum, mas podem determinar efeitos inversos, uma vez que essa característica de repetição, não raro, contribui para a desconstrução de sentidos já consolidados, provocando um enfraquecimento ou deslizamento de sentido.

$\mathrm{O}$ autor assinala, da mesma maneira, que no estereótipo, o indivíduo tem espaço para trabalhar sua diferença e seus sentidos. É uma maneira de proteger a identidade, pois o estereótipo apaga o sujeito, se diluindo na universalidade, não permitindo que ele apareça. "A cristalização dos sentidos produzida pelos estereótipos é, portanto, a possibilidade mesma de deslizamentos de sentidos e de desestabilização de uma memória para tais posições professor e aluno" (COSTA, 2011, p. 93). Todo discurso faz relação com o mesmo e o diferente, portanto o funcionamento discursivo parafrástico pode dar lugar ao funcionamento discursivo polissêmico.

\subsection{Efeitos de sentidos de crise do/no magistério}

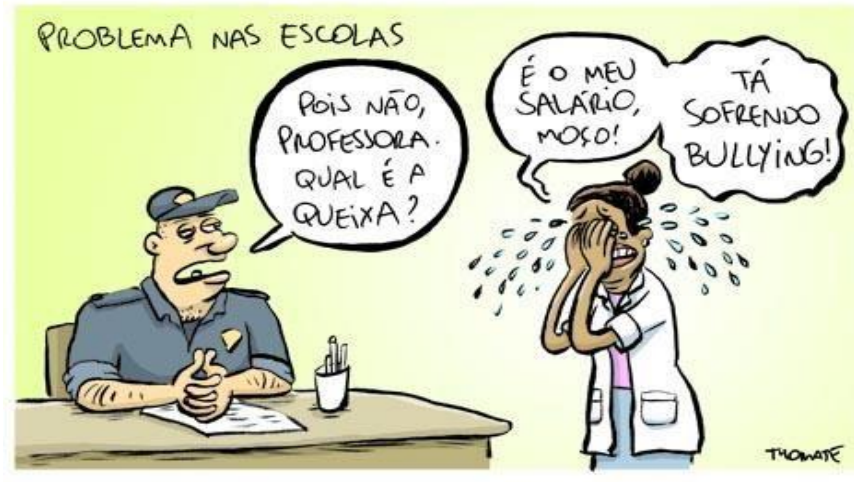

Fig. 1

Fonte: http://nepfhe-educacaoeviolencia.blogspot.com.br/2011/06/educacao-e-salario.html. Acesso em: 16 mar. 2013

Na Figura 1, sintetizada no título "Problema nas Escolas", a professora se apresenta numa delegacia de polícia, órgão institucional que não representa sua categoria, para fazer queixa referente ao seu salário. Na materialidade imagética desta Figura, que mostra uma professora chorando intensamente, percebe-se que ela está atormentada, sentindo-se humilhada, desvalorizada, sem reconhecimento, ressaltando a sua "posição de miséria". Conforme Pereira (2001), o magistério tem sofrido dificuldades materiais e simbólicas, além de se constituir numa posição de "categoria dominada" que, "um tanto profíssionalizada, mal remunerada e [...] em acentuado processo de pauperização, está inclinada a ressaltar as 
SPIES, J.; FISS, D. M. L.

reinvindicações estritamente salariais" (p. 30-31) - o que se confirma por meio da análise da materialidade linguística (intradiscurso) na qual se surpreende a palavra "bullying" associada ao salário. Nesse contexto, a charge mostra que o professor precisa recorrer a instituições que não o representam diretamente para reclamar de uma mantenedora, aparentemente o Estado, que não supre as suas necessidades e dificuldades - o que em outra Figura, a 7, está subentendido pelo título da charge: "Políticos mal intencionados e sem compromisso com a educação".

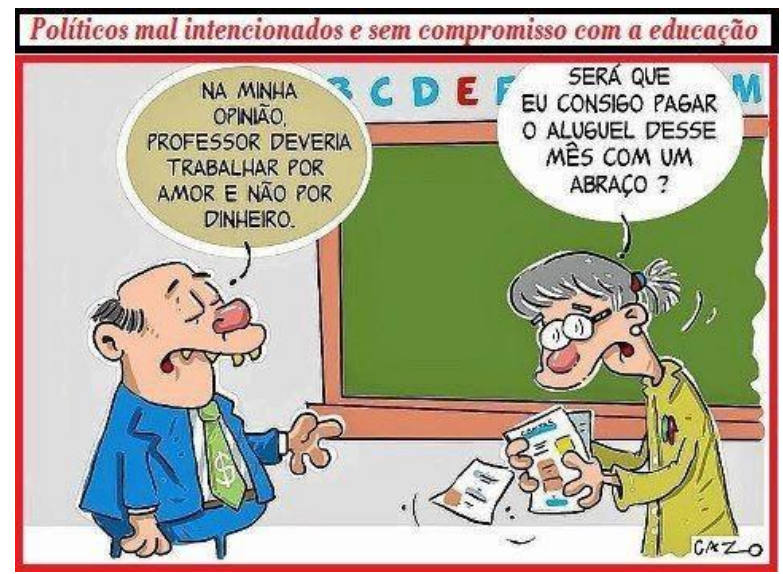

Fig. 7

Fonte: http://carecanoblog.blogspot.com.br/2012/10/dia-do-professor-charge.html. Acesso em: 05 abr. 2013

Como já se disse, a imagem da professora chorando, na Figura 1, sugere o desespero desta ao dar "queixa", explicando "É o meu salário moço! Tá sofrendo bullying!". O sentido desse enunciado revela que a docente já não acredita mais no seu sindicato, na instituição que deve representá-la e lutar pela garantia de seus direitos, procurando apoio numa delegacia, que representa segurança, local para o qual nos dirigimos quando somos agredidos, para pedir ajuda ou proteção. A professora, supõe-se, assume a identidade de alguém que foi agredida em sua dignidade humana, pois seu salário é motivo de chacota, humilhação, degradação. Pelo que parece, nem seus colegas de profissão, que estão envolvidos com o sindicato, conseguem romper esta situação e solucioná-la. Ela procura, assim, apoio em outra instância, a polícia, para ouvir seu desabafo e, quem sabe, restaurar sua posição social ou sua autoestima.

Tanto no discurso dos professores quanto no discurso dos policiais, a expressão “queixa", presente na Figura 1, é corriqueira. Na atualidade, o discurso docente tem tratado de questões didáticas, da sala de aula, da escola e, também, da questão salarial, estando estes assuntos atravessados por "queixas" de toda ordem. O discurso policial se fundamenta na 
"queixa", pois é para este que nos reportamos quando não nos sentimos em segurança. No caso da professora da Figura 1, sua alternativa foi procurar ajuda no espaço que ouve as “queixas" e deve oferecer segurança e proteção.

$\mathrm{Na}$ Análise de Discurso, Orlandi (2012) "considera que a linguagem não é transparente" (p. 17), ou seja, procura ultrapassar a imagem ou texto para encontrar um sentido. Nas dez charges interpretadas existe uma transformação de sentidos, visto que discurso é palavra em movimento, o que envolve um trabalho dos sentidos sobre os sentidos. Um exemplo disso é, exatamente, a relação estabelecida entre as marcas linguísticas "salário" e "bullying" de tal modo que o sentido desta última extrapola o universo de relações entre alunos, no qual os professores costumam identificar situações de bullying, para incluir um outro universo de relações - o dos professores com seus patrões que, a princípio, determinam um salário insuficiente, precarizado. Esta atualização relacionada ao "bullying" e ao salário remete a um funcionamento polissêmico do discurso no qual se evidencia a atualização dos sentidos: todos conhecemos a situação salarial difícil de muitos professores no Brasil, a mídia muito refere os baixos salários, sobretudo, dos professores das redes públicas estaduais ${ }^{5}$, mas a tradução do salário como um objeto sobre o qual se faz chacota é relativamente nova.

$\mathrm{Na}$ Figura 7, pode-se identificar um funcionamento discursivo parafrástico que remete a sentidos que fazem parte da memória sobre ser professor: o chargista apresenta uma professora pedindo ajuda a um político, e este argumenta que o professor deveria trabalhar por “amor". A docente, então, dá a entender que quer pagar com um "abraço" seu aluguel - o que se constitui em marca da ironia do chargista ao fazer a crítica à realidade do magistério em nosso país.

O mesmo ocorre na Figura 8: a professora quer pagar as suas dívidas e procura um agente financeiro, propondo-se a pagar com “amor", que é o que sobra ao final do mês.

\footnotetext{
${ }^{5}$ Nos meses de março e abril de 2013, em consulta a artigos de jornais locais, Zero Hora e Correio do Povo, que tematizam a docência, constatou-se que, em sua maioria, os artigos consultados discorrem sobre os baixos salários, sendo este um argumento recorrente na mídia.
} 


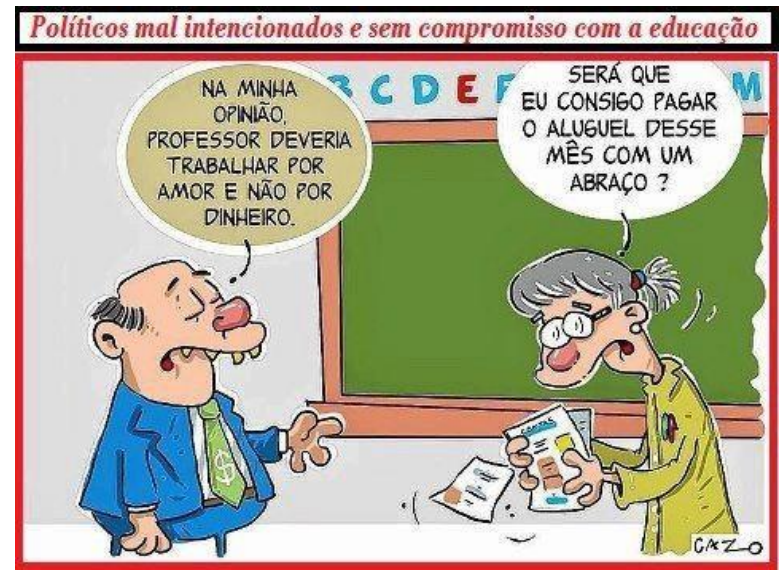

Fig. 7

Fonte: http://carecanoblog.blogspot.com.br/2012/10/dia-do-professor-charge.html.Acesso em: 05 abr. 2013

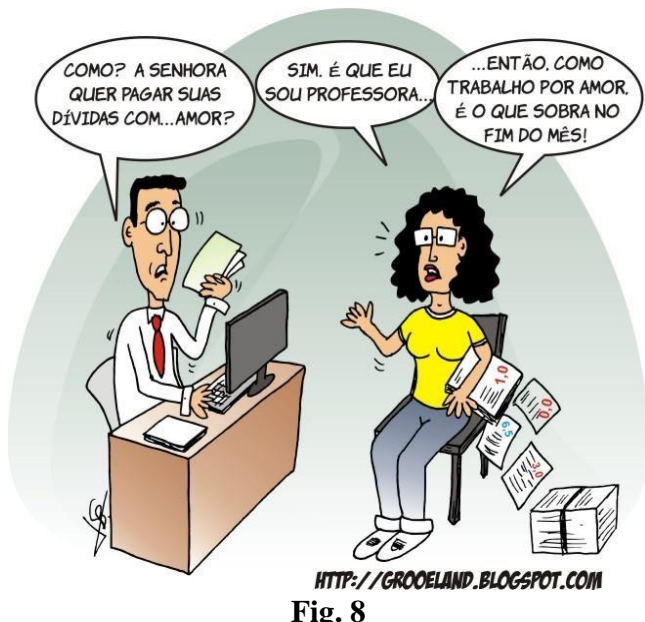

Fig. 8

Fonte:http://grooeland.blogspot.com.br/p/charges.htmlhttp://carecanoblog.blogspot.com.br/2012/10/dia-doprofessorcharge.html.Acesso em: 05 abr. 2013

Nestas Figuras 7 e $\mathbf{8}$ percebemos que existe uma hierarquia entre as instituições: pelo modo como as professoras se dirigem ao político e ao agente financeiro, com um pedido de ajuda, percebe-se alguma dependência em relação às instituições que eles representam. Além disso, a partir da materialidade linguística, dos enunciados, percebe-se a permanência da compreensão da docência como ato de cuidar, ato de amor a ser realizado, provavelmente, pela mulher em função de sua experiência de maternidade e de sua aceitação deste lugar. $\mathrm{O}$ cuidado é visto como uma característica feminina, de acordo com Vianna (2001), "para alguns uma responsabilidade natural, para outros, fruto da socialização das mulheres. Muitas atividades profissionais associadas ao cuidado são consideradas femininas, como a enfermagem, o tomar conta de crianças pequenas, a educação infantil etc.” (p. 93).

$\mathrm{Na}$ Figura 7, o político afirma que "Na minha opinião, o professor deveria trabalhar por amor e não por dinheiro" (grifo nosso), isso nos remete ao que Costa (1996) descreve 
sobre as sociedades gregas e romanas: a partir do século IV a.C., ao surgirem as primeiras escolas para ensinar a ler, escrever e contar, os professores eram discriminados pelo fato de receberem pagamento por seu trabalho. Nessa época, era legalmente proibido cobrar pelo ensino, os professores podiam receber presentes em troca, mas não salário. E, na Figura 8, é a própria professora que menciona o amor como "moeda de troca" quando argumenta: “[...] é que eu sou professora... Então, como trabalho por amor, é o que sobra no fim do mês" - o que, talvez, se constitua em recurso do chargista à ironia de novo.

Costa $(1996,1999)$ e Pereira (2001), ao discutirem questões vinculadas ao trabalho docente e ao profissionalismo, sublinham que a crise do magistério é um fenômeno que tem sido articulado, por muitos estudiosos, exatamente à universalização da escola e à feminização dos quadros docentes - o que deveria ter significado uma possibilidade ampliada de as mulheres participarem nesse campo social. Especificamente, no que se refere à universalização da escola, cabe lembrar que ela se fez acompanhar por um tempo (o século XVIII) em que os professores se tornaram funcionários do Estado, ou seja, passaram a seguir os ditames de um Estado que prometia garantir a identidade do grupo e relativa autonomia na gestão de sua carreira profissional. Assim, a estatização da educação foi um passo para a profissionalização, conseguindo romper com a relação vocacional do professor, visto que antes o modelo de professor era o religioso. Lüdke e Boing (2004) ressaltam que, no entanto, o "grande número de pessoas que a exercem, com diferentes qualificações (e até sem nenhuma especificamente) [...] assim como o crescente número de mulheres” (p. 1169) contribuem para uma certa fragilidade no seu status.

Lüdke e Boing (2004) citam, como se disse antes, que os professores atuam dentro de um sistema subordinado à regulação do Estado, que impõe limites à sua autonomia como grupo ocupacional. As mantenedoras exercem controle sobre os professores, o que resulta em falta de autonomia, colocando assim em dúvida a existência da "profissão" docente. Consoante Fiss (2003),

O sistema escolar, primeiro, admite a competência dos professores, tanto que lhes possibilita o estabelecimento de um vínculo de trabalho, coloca-os na posição de trabalhadores da educação aptos a exercer as funções atinentes a tal papel. Pouco depois, ataca esses profissionais de formas variadas que questionam a referida competência. Seria dizer que, a partir de um certo momento, deixa de tratá-los como profissionais: impõe uma relação de emprego em que os direitos do trabalhador não são respeitados, submete-os a condições de trabalho que não oportunizam, muitas vezes, a possibilidade de continuar estudando. (p. 191). 
SPIES, J.; FISS, D. M. L.

Apesar disso, a escola acaba sendo o espaço onde o professor é considerado um profissional, pois é nesse espaço que o professor é o principal ator pelo qual passam as diferentes culturas.

Se as Figuras 1, 7 e $\mathbf{8}$ indicam que a grande queixa dos professores é a questão salarial, outros sentidos também são percebidos para além do efeito de sentido de desvalorização docente, atrelada à degradação financeira. A professora da Figura 1 lembra a professora tradicional, com seu jaleco, saia e cabelo preso, composição de professora que faz parte do imaginário naturalizado pelo tempo, demonstrando um contraste com a contemporaneidade em que os professores já não se vestem mais de forma padronizada nem gozam do status de outros tempos. A materialidade imagética da Figura 1 evidencia o funcionamento parafrástico do discurso na medida em que retoma um sentido que faz parte da memória sobre a docência.

A feminização do magistério, que ocorreu a partir do final do século XIX, com a entrada das mulheres no magistério, também se constitui uma marca da docência, já que, conforme Costa (1998),

Parece que tudo é amplamente admitido e a contrapartida aparentemente suficiente tem sido reconhecer e justificar que apenas "mulheres afetuosas" e "seres vocacionados" - como as professoras — poderiam assumir a importante "missão social" de educar, recebendo em troca tão pouca retribuição salarial e discutível "reconhecimento social" (p. 2).

O que é marcante nas Figuras analisadas desde uma vez que, das dez consideradas neste trabalho, nove apresentam a imagem da mulher associada à docência e somente em uma aparece a figura de um homem como professor, reforçando, assim, tanto o sentido de feminização da docência como o fortalecimento de um conceito de vocação atribuído, preferencialmente, às mulheres. Essa atribuição da vocação foi historicamente constituída: até o início do século $\mathrm{XX}$, as imagens de professores eram praticamente todas masculinas e foram se modificando a partir da metade do século XX, quando as mulheres professoras começaram a aparecer em imagens. Nóvoa (2009) assinala a este respeito:

Esta alteração, que se justifica também por razões políticas, é acompanhada por uma retórica que reinventa os conceitos de missão ou de vocação, adaptando-os ao universo feminino. Paralelamente, é possível observar um reforço dos dispositivos de controlo dos professores, tanto no plano profissional como no plano pessoal. Os professores do ensino primário tornam-se objecto de uma vigilância apertada, exercida pelas autoridades e pelas comunidades locais, a qual, sobretudo no caso das mulheres, invade as suas vidas privadas (relações, casamento, roupa etc.). (p. 18). 
Isto é perceptível nas Figuras 7 e 8. Nelas, o funcionamento discursivo parafrástico se manifesta na retomada de um sentido antigo, atravessado pela história, em relação ao conceito de vocação do professor: um sujeito que, aos olhos de alguns setores da sociedade, deve exercer o magistério por "amor".

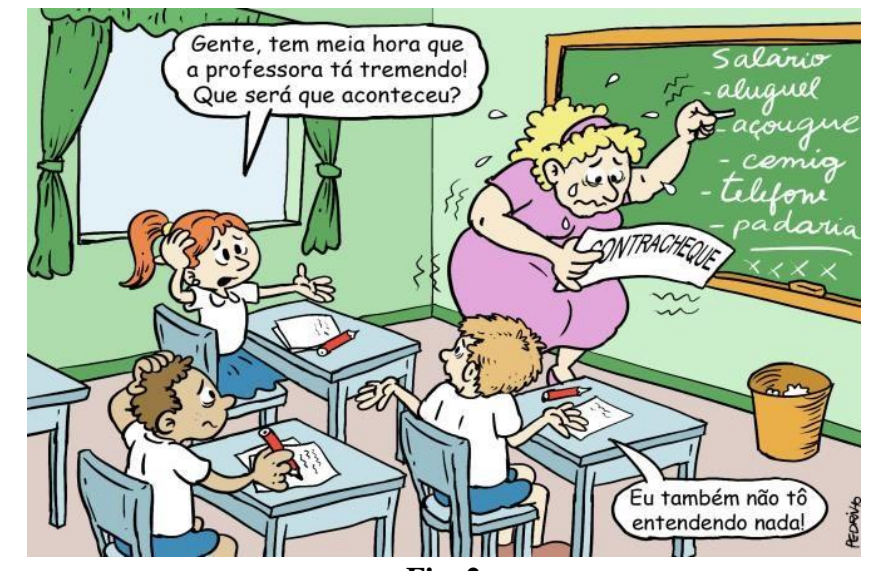

Fig. 2

Fonte: http://nepfhe-educacaoeviolencia.blogspot.com.br/2013/01/professores-e-gestores-querem-mudar.html.Acesso em: 16 mar. 2013

Na Figura 2, a professora aparece aflita e tremendo, dentro da sala de aula, com o contracheque em mãos, fazendo as contas do mês. É possível comparar com os elementos apresentados na Figura 1, em que a "queixa" diz respeito ao salário. Conforme Pereira (2001), “os integrantes do magistério [...] viveram literalmente na pele a dura experiência da desvalorização salarial, da perda do amor-próprio e da queda-livre do prestígio profissional, isto é, do diploma e das credenciais simbólicas" (p. 43). A Figura 2 demonstra o que tem acontecido com os professores, deixando-os sem referências de como proceder na sala de aula, pois a maior preocupação é com o salário, que é insuficiente para uma vida digna. Uma realidade como esta afeta, também, o amor-próprio - o que está representado na materialidade imagética da charge: uma professora curvada, chorando, preocupada com as contas.

As questões de sala de aula, os alunos, estão em segundo plano na Figura 2, o que é demonstrado pelo sentido de perplexidade manifesto nas falas dos alunos (materialidade linguística): "Que será que aconteceu?" e "Eu também não tô entendendo nada!", e em seus gestos (materialidade imagética): levando as mãos à cabeça, abrindo os braços, coçando a cabeça, um aluno olhando para o outro com semblante de espanto. Importante assinalar que os pontos de interrogação e exclamação no final das falas dos alunos representam seus sentimentos de surpresa e de espanto, não entendendo a postura da professora que treme na 
SPIES, J.; FISS, D. M. L.

frente do quadro-negro e não promove o trabalho pedagógico do modo como eles esperam - o que afeta a relação da professora com os alunos.

O ambiente em que o chargista retrata a professora é uma sala de aula com quadronegro, giz, alunos uniformizados, classes enfileiradas, lembrando um sentido de sala de aula ainda bastante comum em que o professor ensina, expõe os conteúdos, e os alunos recebem as informações. Portanto, as imagens evidenciam um funcionamento parafrástico do discurso. No entanto, a atitude da professora ao não abordar os conteúdos escolares, mas as questões salariais, que são conteúdos de sua vida, atualizam os sentidos na medida em que expressam a compreensão da sala como mais do que um espaço de transmissão de conhecimento: a sala de aula é interpretada como lugar onde se fala sobre as coisas da vida também e, além disso, estas coisas da vida, sintetizadas como "questões salariais", afetam a prática pedagógica e a relação com os alunos. Portanto, percebe-se também o funcionamento polissêmico do discurso nas imagens e palavras da Figura 2.

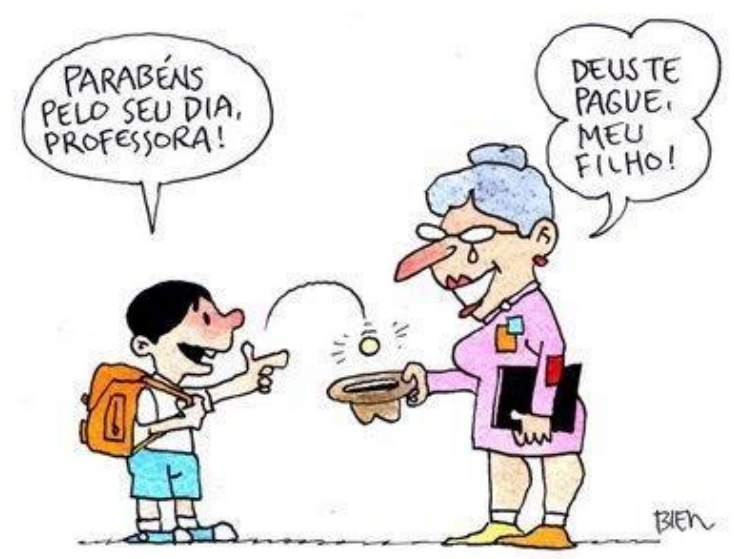

Fig. 3

Fonte: http://freelancerdigital.blogspot.com.br/2010/10/dia-do-professor-nossa-homenagem.html. Acesso em: 16 mar. 2013

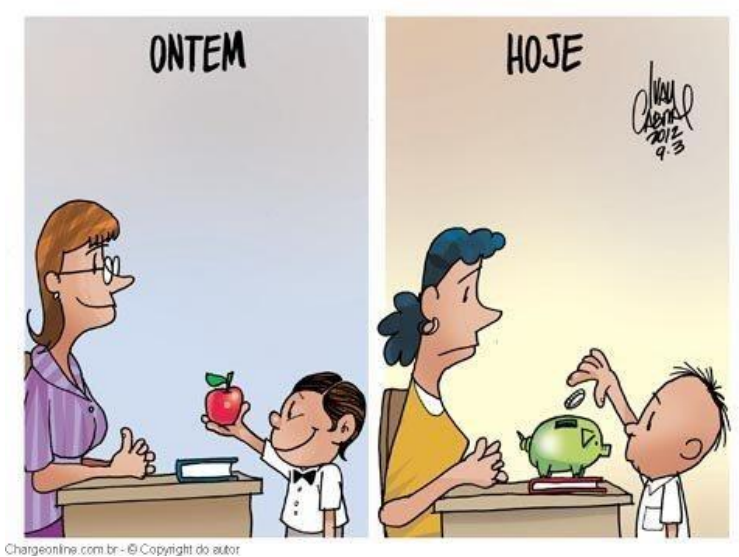

Fig. 4

Fonte: http://sintserp.blogspot.com.br/2012_03_01_archive.html.Acesso em 16 mar. 2013 


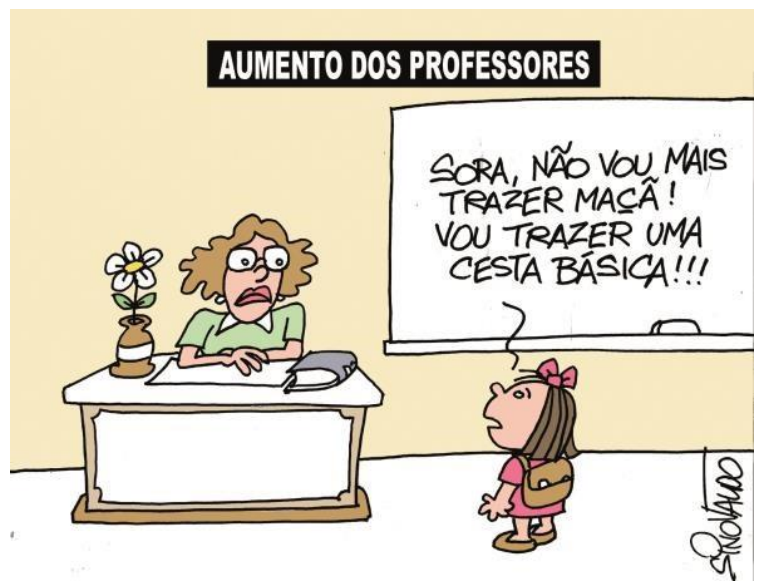

Fig. 5

Fonte: http://amaieski.files.wordpress.com/2013/01/sino-abc-1301-2013-cmyk.jpg.Acesso em: 20 mar. 2013

Nas Figuras 3,4 e 5, a questão salarial dos professores compreende também as relações pedagógicas com os alunos, observado pelo comportamento dos discentes. Antigamente, como demonstra a Figura 4, à esquerda, os estudantesprocuravam afagar o professor com um mimo, gesto que ainda pode ser observado nos tempos atuais: alguns alunos continuam presenteando os seus professores com bombons, flores, cartões, e isto sublinha certo funcionamento discursivo parafrástico que se surpreende nas imagens. No entanto, o que também pode se observar nas Figuras 3, 4 e 5 são situações em que os alunos demonstram outro tipo de preocupação com o docente e, com a intenção de auxiliar, oferecem comida e até esmola aos professores, revelando um funcionamento discursivo polissêmico.

A relação entre paráfrase e polissemia, presente nas Figuras 3, 4 e 5, como se observou anteriormente, se traduz em "[...] fenômeno que decorre do modo de funcionamento discursivo da mudança que, quando promove uma ruptura, o faz a partir de uma relação com o mesmo e se constitui, então, enquanto retorno e interpretação do mesmo, do já dito." (FISS, 1998, p. 52-53). Dessa maneira, o chargista chama a atenção, de forma crítica e bemhumorada, para a realidade do magistério em nosso país, relacionando o sentido de respeito pelo professor por parte do aluno, que oferece algum tipo de "presente" (maçã, cesta básica ou moedas), ao sentido de precarização da docência que abrange sua sobrevivência e suas condições de vida.

$\mathrm{Na}$ Figura 5, a aluna sugere que vai presentear a professora com uma cesta básica ao contrário da tradicional maçã. Nas Figuras 3 e 4 (à direita), os alunos optam por uma moeda, sugerindo uma esmola para o professor. Na Figura 3, aparece uma professora com um coque, lembrando uma imagem de professora que é bastante comum em livros e revistas de décadas passadas, o que evidencia um funcionamento discursivo parafrástico, em contrapartida suas 
SPIES, J.; FISS, D. M. L.

roupas têm remendos, ela usa meias de cores diferentes e um chapéu que evidencia um sentido de professor-mendigo, mal remunerado, evidenciando um funcionamento discursivo polissêmico. Conforme Lüdke e Boing (2004), o “declínio da profissão docente” tem relação com a decadência do seu salário, posto que, historicamente, há 30 ou 40 anos, o salário do professor era garantia de vida digna para as solteiras ou, então, ajuda no orçamento familiar para as professoras casadas.

Todavia, conforme Nóvoa (2009), além do necessário reconhecimento pelo incremento salarial, "nas sociedades contemporâneas, o prestígio de uma profissão mede-se, em grande parte, pela sua visibilidade social” (p. 21). Com isso, o autor português nos coloca diante de uma questão decisiva, pois os programas de formação de professores deverão compreender essa realidade como um desafio, haja vista que a sobrevivência da profissão de professor depende da qualidade do trabalho das escolas e, também, de sua capacidade de intervir no espaço público da educação.

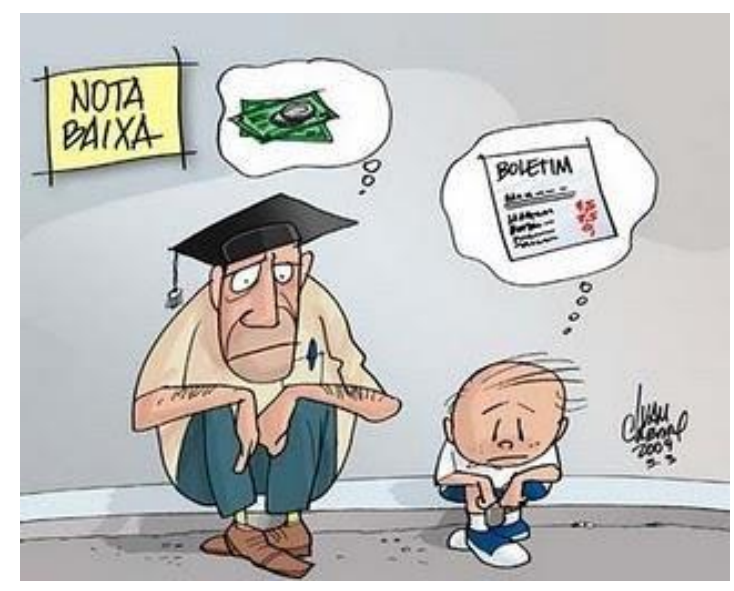

Fig. 6

Fonte: http://www.ivancabral.com/2009/03/charge-do-dia-nota-baixa.html.Acesso em: 17 mar. 2013

Na Figura 6, aparece um professor do gênero masculino, graduado - o que é confirmado pelo uso do barrete ou chapéu - ao lado de um aluno. O chargista revela uma certa heterogeneidade de sentidos: para o aluno "nota baixa" representa conceito, e para o professor "nota baixa" é o valor pecuniário que recebe pelo exercício de sua profissão. Nesse processo polissêmico, a transformação dos sentidos da marca linguística "nota baixa" lembra o que diz EniOrlandi (2012): “o que temos é um deslocamento, ruptura de processos de significação" (p. 36).

Além disso, o chargista demonstra, na Figura 6, a presença ainda discreta do gênero masculino no magistério, pelo menos, na Educação Infantil e nos Anos Iniciais do Ensino 
Fundamental. De acordo com o site UOL Educação ${ }^{6}$, as mulheres compõem $81,5 \%$ do total de professores da Educação Básica do país. Os dados foram divulgados pelo MEC (Ministério da Educação) em 2010: são quase 2 milhões de professores, dos quais mais de 1,6 milhão são mulheres. Ainda, soma-se a isto, o fato de que o único professor encontrado no levantamento de 69 charges que fazem referência à docência, publicadas entre 2003 e 2013, é representado de forma desanimada, decepcionada com seu salário. Para Sá e Rosa (2004), "Mesmo depois de mais de cem anos, a evasão dos homens da profissão docente continua sendo a justificativa pelos baixos salários e pelo desprestígio da profissão" (p. 1). Cabe frisar que, segundo estes autores, os homens desistem da carreira, indo em busca de profissões com melhor remuneração.

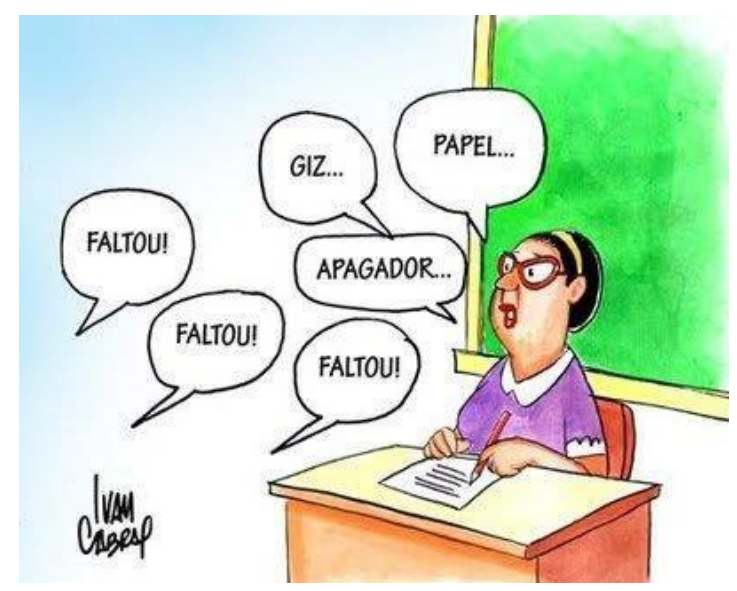

Fig. 9

Fonte: http://mestrevirtual.blogspot.com.br/2012/02/itens-da-escola-ivan-cabral.html.Acesso em: 17 mar. 2013

A precarização do espaço escolar também se apresenta na Figura 9, na qual a professora, sentada à frente da classe, faz uma "chamada" simbólica dos materiais que faltam na sala de aula. De acordo com Lüdke e Boing (2004),

a "profissão" docente exibe, mesmo aos olhos do observador comum, sinais
evidentes de precarização, visíveis pela simples comparação com datas passadas. À
parte a nostalgia, que em geral valoriza mais o que já passou ("a minha escola", "a
minha professora"), não é difícil constatar a perda de prestígio, de poder aquisitivo,
de condições de vida e, sobretudo, de respeito e satisfação no exercício do
magistério hoje. (p. 1160).

Essa precarização fica evidente nas dez figuras analisadas bem como um sentido de crise do/no magistério: elas não só apontam a carência de materiais, mas sugerem também a

\footnotetext{
6 Disponível em: http://educacao.uol.com.br/noticias/2011/03/03/brasil-8-em-10-professores-daeducacaobasica-sao-mulheres.htm. Acesso em 19 de junho de 2013.
} 
SPIES, J.; FISS, D. M. L.

precarização do profissional docente por meio de marcas que reconhecemos no intradiscurso (materialidades imagética e linguística) - a falta de material, a questão salarial, o desprestígio associado historicamente à feminização, a desvalorização, a desmotivação. Na Figura 10, apresentada logo a seguir, se evidencia a ausência do professor ou, como é também chamado, o absenteísmo que tem sido relacionado ao mal-estar que se origina das condições em que se produz a docência em nosso país.

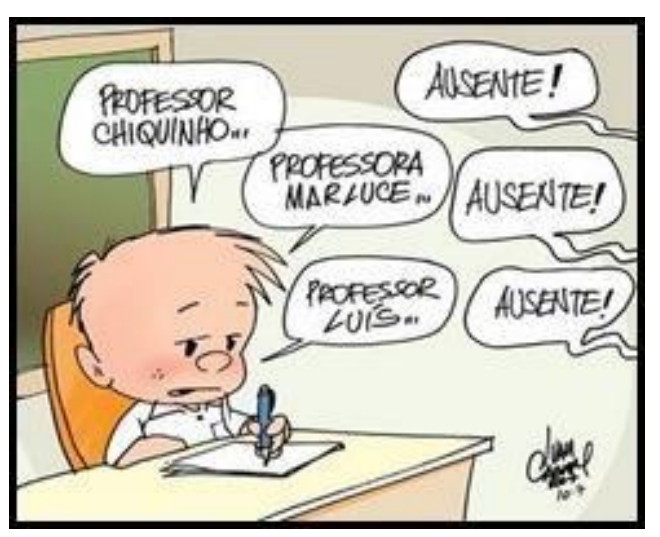

Fig. 10

Fonte: http://www.essaseoutras.xpg.com.br/wp-content/uploads/2011/05/charge-sobre-educacao.jpg.Acesso em 16 mar. 2013

Observa-se, na materialidade imagética, uma sala de aula com o quadro verde e um aluno, sentado à mesa do professor, fazendo a chamada. A materialidade linguística nos surpreende no momento em que percebemos que são os professores os chamados e eles estão ausentes. Pode-se supor, a partir dessa imagem, uma realidade presente no espaço escolar: a ausência de professores em sala de aula, no espaço escolar por vários motivos - desprestígio, medo, doença, desmotivação, condições precárias de trabalho, etc. Em resumo, condições que os professores enfrentam diariamente e que remetem a um sentido de ausência bem mais amplo do que essa ausência física do docente, em um espaço onde se esperava que ele estivesse presente. Um sentido de ausência que remete às muitas realidades com que se defronta o educador. Realidades referidas ao longo desta análise e que se associam a sentidos de desvalorização do professor, sentidos de crise do/no magistério, sentidos de ausência de prestígio, ausência de condição de trabalho, ausência de representatividade junto à sociedade.

\section{RETICÊNCIAS}

Os professores têm assumido diversas identidades, nem fixas, nem permanentes, mas que se alteram conforme o contexto em que estes sujeitos estão inseridos. A identidade édefinida historicamente e está em constante formação e transformação. Essa mutação fica 
evidente nas charges analisadas, uma vez que evidenciam sentidos acerca da docência que são retomados ou atualizados.

Nas charges, produzindo certa naturalização de sentidos, o magistério é associado a vocação, feminização, hierarquização, precarização salarial, desprestígio, condições precárias de trabalho. As análises produzidas sobre as charges permitem perspectivar que as pessoas não identificam mais seus interesses apenas por relações de classe, mas elas mudam sua identidade de acordo com o modo como são interpeladas ou representadas, nem sempre sendo sua identificação automática e podendo ser ganhada ou perdida. Elas revelaram um funcionamento discursivo parafrástico, em que sentidos são retomados, e também um funcionamento discursivo polissêmico, em que sentidos são atualizados, produzindo, assim, marcas nos nossos modos de compreensão das identidades docentes e da docência. No entanto, outro questionamento pertinente surgiu a partir das análises: como as ausências no espaço escolar repercutem ou remetem aos sentidos de crise do/no magistério? Questão relacionada ao absenteísmo do professor, à ausência de autoridade, de prestígio, de representatividade evidenciados na última charge analisada e também presentes, sob certo aspecto, nas outras 68 charges selecionadas para este estudo.Questão que aponta para a necessidade de continuidade da pesquisa dada a relevância do tema e das descobertas feitas no estudo sobre o qual este artigo discorre.

\title{
CHARGES' EDUCATIONAL IDENTITIES AND CRISES OF/ON THE MAGISTERIUM: SENSE EFFECTS
}

\begin{abstract}
There are several ways of being said and made a teacher - which also triggers the thought: How do the constituted representations produce effects on the production of sense in being a teacher? How can they influence us? Being these the research issues, we intend to comprehend the sense effects manifested in a specific textual genre - the charge. This study is a qualitative research based on the French Discourses analysis (Michel Pêcheux). Ten charges were analyzed, seeking to realize senses associated to teachers based on Stuart Hall, AntónioNóvoa, Maurice Tardif, Gilson Pereira, Cláudia Pereira Vianna, Marisa Vorraber Costa, MengaLüdke and Eni P. Orlandi. The crises sense effect of/ on the magisterium appeared in the charges linked with the wage casualization, teaching feminization, different
\end{abstract}


SPIES, J.; FISS, D. M. L.

relationships with students and with certain institutions, referring to a production of senses around the teacher that evidences both paraphrastic and polysemic discursive production.

Keywords: Educational Identities; Charges; Speech

\section{IDENTIDADES MAESTROS, CARGOS Y CRISIS DE/EN ENSEÑANZA: EFECTOS DE LOS SENTIDOS}

\section{Resumen}

Hay muchas maneras de decir/hacer profesor, ¿Qué piensan acerca de: cómo las representaciones tendrán efecto sobre la producción de significados acerca de ser un maestro? ¿Cómo pueden influir en nosotros? Estos son los temas de la investigación cualitativa apoyados por el análisis del discurso francés (Pêcheux), nuestro objetivo es comprender los efectos de significados expresados en un género específico - un cargo. Se analizaron diez dibujos animados, mirando percibir significados asociados a los maestros basados en Stuart Hall, Antonio Novoa, Maurice Tardif, Gilson Pereira, Claudia Pereira Vianna, Marisa Vorraber Costa, MengaLüdke y Eni P. Orlandi. El sentido del efecto de la crisis de la enseñanza apareció en los dibujos animados articulados inseguridad salarial, feminización de la enseñanza, la diferente relación con los estudiantes y con ciertas instituciones, en referencia a una producción de sentido en torno a la enseñanza que muestra tanto un funcionamiento discursivo paraphrastic como polisémico.

Palabras clave: Maestros identidad; Cargos; Discurso

\section{REFERÊNCIAS}

BRASIL

ESCOLA.

Bullying.

Disponível

em:

http://www.brasilescola.com/sociologia/bullying.html. Acesso em: 23 Jun. 2015.

COSTA, Marcos de Sá. Estereótipo e paráfrase, resistência e polissemia: charges sobre educação em uma perspectiva da análise do discurso. 203 f.2011. Dissertação (Mestrado) Universidade Federal Fluminense, Instituto de Letras. 
COSTA, Marisa Vorraber. O magistério e a política cultural de representação e identidade. Anais do V Congresso Estadual Paulista, Águas de São Pedro, São Paulo, novembro de 1998. http://www.ufrgs.br/neccso/downloads_pesquisadores.html. Acesso em: 23 Jun. 2015.

COSTA, Marisa V. Trabalho docente e profissionalismo: poder, saber e suas tramas. In: MORAES, Vera Regina Pires et al. (org.). Melhoria do ensino e capacitação docente: programa de atividades de aperfeiçoamento pedagógico.Porto Alegre: Ed. Universidade/UFRGS, 1996.

DICIONÁRIO INFORMAL. Idiossincrasia. Disponível em: http://www.dicionarioinformal.com.br/idiossincrasia/ Acesso: 23 Jun. 2015.

FISS, Dóris Maria Luzzardi. Os processos de construção da autoria e do mal-estar docente numa escola pública estadual.Porto Alegre: UFRGS, 1998. 228 f. Dissertação (Mestrado). Universidade Federal do Rio Grande do Sul, Faculdade de Educação, Programa de PósGraduação em Educação.

Territórios incertos:os processos de sujetivação das professoras da rede pública estadual. Porto Alegre: UFRGS, 288 f. 2003. Tese (Doutorado). Universidade Federal do Rio Grande do Sul, Faculdade de Educação, Programa de Pós-Graduação em Educação.

HALL, Stuart. A identidade cultural na pós-modernidade.7. Ed. Belo Horizonte: DP\&A, 2003.

Identidade cultural e diáspora. Revista do Patrimônio Histórico e Artístico Nacional, Brasília: Instituto do Patrimônio Histórico e Artístico Nacional, Ministério da Cultura,n. 24, Fev. 1996. Disponível em: http://www.iphan.gov.br/baixaFcdAnexo.do?id=3201Acesso: 23 Jun. 2015.

HUBERMAN, Michael. O ciclo de vida profissional dos professores. IN: NÓVOA, Antonio (org.). Vidas de professores. Porto: Porto Editora, 1995.

LÜDKE, Menga e BOING, Luiz Alberto. Caminhos da profissão e da profissionalidade docentes. Educação \& Sociedade, Campinas: Unicamp, vol. 25, n. 89, Set./Dec. 2004.http://www.scielo.br/pdf/es/v25n89/22616. Acesso em: 23 Jun. 2015.

MIANI, RozinaldoAntonio. Charge: uma prática discursiva e ideológica, 9a Arte - Revista Brasileira de Pesquisa em Histórias em Quadrinhos, São Paulo: Observatório de Histórias em Quadrinhos, USP, vol. 1, n. 1, 2012. Disponível em: http://www2.eca.usp.br/nonaarte/ojs/index.php/nonaarte/article/view/3/7. Acesso: 23 Jun. 2015.

MINAYO, Cecília (Org.). Pesquisa social: teoria, método e criatividade. 25. ed. Petrópolis: Vozes, 2007.

NÓVOA, António. Professores:imagens do futuro presente. Lisboa: EDUCA, 2009. 
SPIES, J.; FISS, D. M. L.

NÓVOA, António. As Palavras das Imagens: retratos de professores (Séculos XIX-XX), Atlântida - Revista da Cultura, vol. XLVI, 2000. Disponível em: http://repositorio.ul.pt/bitstream/10451/671/1/21231_1646-1002_101-122.pdf. Acesso em: 23 Jun. 2015 .

NÓVOA, António. Vidas de professores. Porto: Porto Editora, 1995

OLIVEIRA, Neide Aparecida Arruda de \& ALMEIDA, Lara Monique. Gêneros jornalísticos opinativos de humor: caricaturas e charges, Janus - Revista de Pesquisa Científica, Lorena: Instituto de Pesquisa e Iniciação Científica da FATEA, Centro Cultural Teresa D'Ávila, Ano 3, n. 4, 2006.http://publicacoes.fatea.br/index.php/janus/article/viewFile/38/41

ORLANDI, Eni P. Análise de Discurso:princípios e procedimentos. Campinas: Pontes Editores, 2012.

PEREIRA, Gilson R. Servidão ambígua:valores e condições do magistério. São Paulo: Escrituras Editora, 2001.

SÁ, Carolina Mafra de. ROSA, Walquíria Miranda. A história da feminização do magistério no Brasil: uma revisão bibliográfica. Anais do III Congresso Brasileiro de História da Educação - Educação Escolar em Perspectiva Histórica, Pontifícia Universidade Católica do Paraná, Sociedade Brasileira de História da Educação, Curitiba, 2004. Disponível em: http://sbhe.org.br/novo/congressos/cbhe3/paginas/cbhe.htm. Acesso em: 23 Jun. 2015.

TARDIF, Maurice. Saberes docentes e formação profissional.14. ed. Petrópolis, RJ: Vozes, 2012.

TARDIF, Maurice. Saberes profissionais dos professores e conhecimentos universitários. Revista Brasileira de Educação - ANPEd,Rio de Janeiro: Editora Autores Associados,Jan./Fev./Mar./Abr. 2000, n. 13. Disponível em: http://anped.org.br/rbe/rbedigital/RBDE13/RBDE13_05_MAURICE_TARDIF.pdf. Acesso em: 23 Jun. 2015.

TARDIF, Maurice \& RAYMOND, Danielle. Saberes, tempo e aprendizagem do trabalho no magistério. Educação \& Sociedade, Campinas: Unicamp,vol. 21, n. 73, Dec. 2000. Disponível em: http://www.scielo.br/pdf/es/v21n73/4214. Acesso em: 23 Jun. 2015.

UOL EDUCAÇÃO. Brasil:8 em 10 professores da educação básica são mulheres. Disponível em: Disponível em:http://educacao.uol.com.br/noticias/2011/03/03/brasil-8-em-10professores-da-educacao-basica-saomulheres.htm. Acesso: 23 Jun. 2015.

VIANNA, Cláudia Pereira. O sexo e o gênero da docência. Cadernos Pagu [online], Campinas: Núcleo de Estudos de Gênero - Pagu/Unicamp, n. 17-18, 2002. Doi: http://dx.doi.org/10.1590/S0104-83332002000100003.

Data de recebimento: $18 / 02 / 2015$

Data de aceite: 10/03/2015 